\title{
Custos hospitalares com crianças e adolescentes vítimas de traumatismos no Estado de Pernambuco em 1999
}

\author{
Hospital costs of trauma-related hospitalizations of children and adolescents
}

in the State of the Pernambuco in 1999

Roberto Natanael da Silva Mendonça', João Guilherme Bezerra Alves²

\section{RESUMO}

Avaliou-se os gastos do Sistema Único de Saúde (SUS) com internações hospitalares de crianças e adolescentes, vítimas de traumatismos no estado de Pernambuco, no ano de 1999. Utilizou-se o banco de dados do Sistema de Informações Hospitalares do DATASUS, construído a partir das informações contidas nas Autorizações de Internação Hospitalar (AlH). Foram registradas 9.220 internações por causas externas a um custo de $\mathrm{R} \$ 3.659 .558,62$, sendo 7.807 por traumatismos $(84,7 \%)$. O custo médio no estado de Pernambuco nesse ano, para as internações por todos os diagnósticos na faixa etária de 0 a 19 anos, foi de $R \$ 306,49$. Quando se computou apenas os traumatismos o custo médio passou para $R \$ 370,66$. Os maiores gastos ocorreram com os traumatismos intracranianos e as fraturas de membros superiores e inferiores.

Descritores: Traumatismo; Custos Hospitalares; Fraturas.

\section{INTRODUÇÃO}

O trauma é a causa mais freqüente de morte em pessoas com menos de 44 anos de idade. Representa hoje, um dos principais problemas de saúde pública tanto para os países ricos como para os pobres. Além de provocar forte impacto sobre as taxas de morbimortalidade, apresenta importantes repercussões econômicas. O custo do trauma à comunidade inclui além dos gastos diretos com o tratamento, os custos indiretos com a perda da produtividade, especialmente quando se trata de crianças e adolescentes pela maior expectativa de vida ${ }^{(5,11)}$.

Os traumatismos custam anualmente $\$ 425$ bilhões de dólares aos americanos $^{(4)}$. Na América Latina, estima-se que os custos econômicos anuais de mortes e invalidez resultado de atos violentos representem aproximadamente $20 \%$ dos gastos totais de cada país com a saúde ${ }^{(13)}$.

É difícil avaliar por completo o seu verdadeiro impacto econômico. Afora os custos médicos do tratamento e reabilitação da vítima, estão envolvidos habitualmente gastos com os sistemas judiciário e penal, os custos sociais com a queda de produtividade, além de perdas materiais decorrentes dos agravos ${ }^{(9)}$. Mesmo em países ricos, o aumento da demanda de serviços por essas vítimas, ao lado da maior complexidade do atendimento ao paciente com trauma - muitas vezes envolvendo tecnologia complexa - está provocando a desativação de

\section{SUMMARY}

The Brazilian National Unified Health System (SUS) expenditures related to hospitalizations of trauma children and adolescents in the Pernambuco State in 1999. were evaluated. Data were collected from the databank of the Hospital Information System of the DATASUS, based on information recorded on the Hospitalization Authorization Forms (AlH). A total of 9,220 hospital admissions by external causes were identified with a cost of $R \$ 3,659,558.62$, with 7,807 hospitalizations due to trauma (84.7\%). The mean cost of hospital admissions for children and adolescents in the Pernambuco State this year was $R \$$ 306.49 versus a mean cost of hospital admissions for trauma of $R \$$ 370.66. Head trauma and limb fractures were associated with higher costs.

Key words: Wounds and injuries; Hospital costs; Fractures.

\section{INTRODUCTION}

Trauma is the most frequent cause of death in subjects aged $<44$ years. It is one of the most important public health problems both in developed and developing countries. It has a great effect upon morbimortality rates and is associated with a significant economical burden. The trauma costs include direct costs associated with treatment and indirect costs associated with productivity loss, specially when children and adolescents are the victims because of the greater life expectancy $(5,11)$.

Annual trauma costs amount to US $\$ 425$ billion in the USA ${ }^{(4)}$. In Latin America, the estimated annual economic costs associated with death and disability due to violence amount to approximately $20 \%$ of the total budget of the Health Ministry in each country.(13).

The true economic impact of trauma is difficult to evaluate. Not only the medical costs of treatment and rehabilitation, but also the costs related to the judicial and penal systems, the social costs of productivity loss, and material losses due to injuries must be taken into account ${ }^{(9)}$. Even in developed countries, the increased demand for services requested by these victims, together with the greatercomplexness of trauma management - sometimes involving complex technologies - has led to the deactivation of trauma care centers due to escalating costs ${ }^{(2)}$. The Pan-American Organization of Health reports that
Trabalho realizado no Instituto Materno Infantil de Pernambuco (IMIP)

1 - Mestre em Saúde Materno Infantil pelo IMIP

2 - Professor Adjunto da UPE e do IMIP

Endereço para correspondência: Rua dos Coelhos, 300, Boa Vista CEP: 50070-550 - Recife - PE

E-mail: joaoguilherme@imip.org.br
Work performed at Maternal-Infantile Institute of Pernambuco (IMIP)

1 - Mastership in Maternal-Infantile Health - IMIP

2 - Associate Professor at the UPE and IMIP

Adress: Rua dos Coelhos, 300, Boa Vista

CEP: 50070-550 - Recife - PE

E-mail: joaoguilherme@imip.org.br 
centros de trauma pela importante elevação dos custos ${ }^{(2)}$. A Organização Panamericana da Saúde (OPAS, ) relata que os casos de trauma chegam a consumir entre 8 a 10\% do orçamento de cada hospital que mantém pronto-socorro. No Brasil, com o fenômeno do incremento da violência, os casos de traumas vem apresentando um importante aumento. Deslandes et al. ${ }^{(4)}$, detectaram um aumento de $69 \%$ nos gastos federais para o atendimento de vítimas de violência na região metropolitana do Rio de Janeiro entre os anos de 1991 e 1993. Assim, apesar de elevados, ainda não são bem conhecidos os custos acarretados com os eventos violentos.

A obtenção de dados econômicos associados com os traumatismos apresenta importantes razões, como a identificação precisa do seu impacto, incluindo um maior poder de sensibilização das lideranças políticas, do que os próprios dados epidemiológicos. A segunda, é servir como parâmetro para avaliação das intervenções postas em prática no combate à violência.

Considerando a importância do tema bem como o fato de o estado de Pernambuco, figurar com destaque no panorama da violência nacional com importante crescimento da mortalidade por causas externas nos grupos etários mais jovens ${ }^{(1)}$, foi objetivo desse estudo verificar os gastos do Sistema Único de Saúde (SUS) neste estado com os internamentos de crianças e adolescentes por traumas no ano de 1999

\section{MATERIAL E MÉTODOS}

\section{Local do estudo}

O Estado de Pernambuco possui cerca de 184 municípios, além do Distrito Estadual de Fernando de Noronha, sendo a capital do Estado - a cidade de Recife - o município mais populoso, com cerca de 1.421.947 habitantes em agosto/2000. A população do Estado era de 7.910.992 pessoas, com uma densidade demográfica de 78,37 habitantes $/ \mathrm{km}^{2}$ e uma concentração de $76,5 \%$ nas áreas urbanas. A população estimada entre 15 e 19 anos era de 859.450 pessoas. No ano de 1999, o total de leitos disponíveis no Estado para o SUS era de 21.916, dos quais 11.906 (54,33\%) apenas na Região Metropolitana do Recife(2).

\section{Dados}

Foi realizado um estudo descritivo, cuja fonte de informação foram os arquivos reduzidos da base de dados, em CD-ROM, do Sistema de Informações Hospitalares do Sistema Único de Saúde (SIH-SUS) do DATASUS, relativa ao ano de 1999 (MS, 1999) no estado de Pernambuco, com informações hospitalares obtidas dos formulários de Autorização de Internação Hospitalar (AlH). Utilizou-se a AlH 1, que contém registro de identificação do paciente, procedimentos, diagnose e tratamento realizado, acompanhado dos respectivos códigos das afecções diagnosticadas. Foi construído um banco de dados com os códigos de diagnóstico principal, segundo o CID-10, incluídos nos capítulos XIX e XX, sendo selecionada a população de 0 a 19 anos de idade.

\section{RESULTADOS}

Durante o ano de 1999, ocorreram em Pernambuco 190.485 hospitalizações para todos os diagnósticos, na faixa etária de 0 a 19 anos de idade. Destas, cerca de 9.220 foram motivadas por causas externas $(4,8 \%)$, sendo 7.807 por traumatismos; $71,4 \%$ no sexo masculino e 55,3\% entre 10 a 19 anos. trauma care costs amount to $8 \%$ to $10 \%$ of the budget of hospitals provided with emergency room. In Brazil where violence has markedly increased, a marked rise in the number of trauma cases has being seen. Deslandes et al. ${ }^{(4)}$ have found an increase of $69 \%$ in federal expenditures related to the management of violence victims in the urban area of the Rio de Janeiro city during 1991-1993. Costs associated to violence are high but have not yet been clearly established.

Accurate trauma-related economic data are important for two reasons: the precise identification of trauma impact since this can be more effective in sensitizing political leaders than epidemiological data; they must be used as a parameter for the evaluation of the interventions adopted against violence.

The present study aims to identify trauma-related hospitalization costs of children and adolescents to the Brazilian National Unified Health System (SUS) during 1999 due to the importance of the matter and also because the Pernambuco State holds a prominent rank in the national violence panorama with a significant increase in mortality due to external causes in younger groups ${ }^{(1)}$.

\section{MATERIAL AND METHODS}

\section{Study site}

There are approximately 184 counties and the State District of Fernando de Noronha in the Pernambuco state; the Pernambuco capital, the Recife city, is the most populous county with approximately 1,421,947 inhabitants in August/2000. The State population was 7,910,992 subjects with a demographic density of 78.37 inhabitants/ $\mathrm{km}^{2}$ and a concentration of $76.5 \%$ in the urban areas. The estimated population aged 15-19years was 859,450 subject. In 1999, the total of beds available in the State for the SUS was 21,916 subjects, 11,906 of them (54.33\%) located in the urban area of Recife(2).

\section{Data}

A descriptive study was carried out using as an information source the summarized files of the CD-ROM database of the Hospital Information System of the Brazilian National Unified Health System (SIH-SUS) of DATASUS for the Pernambuco State in 1999 (Health Ministry, 1999). Hospital information were taken from the Hospitalization Authorization forms (AlH). AlH1 containing patient's identification, procedures, diagnosis, and treatments, accompanied by the respective codes of diagnosed diseases or conditions was used. A databank was then produced with the codes of the main diagnosis, according CD-10, included in chapters XIX and XX; the selected population was aged 0-19 years.

\section{RESULTS}

There were 190,485 hospitalizations of patients aged 0-19years for all diagnoses in the Pernambuco state during 1999. Approximately 9,220 of them were due to external causes (4.8\%) with 7,807 due to traumas; more male patients $(71,4 \%)$ aged $10-19$ years were hospitalized than female patients of the same age (55.3\%).

The total cost to the SUS of hospitalizations for all age groups was $R \$ 212,073,716.90$ in Pernambuco in 1999. When one considers hospitalization of patients aged $<19$ years, the cost was $R \$$ $58,382,850.70$ (mean cost of $R \$ 306.49$ per patient). Diseases and conditions included in chapters XIX and XX corresponded to $6.27 \%$ of 
O custo total dos internamentos para todas as faixas etárias em Pernambuco, no ano de 1999, representou para o SUS cerca de R $\$$ 212.073.716,90. Considerando-se apenas a faixa etária até os 19 anos, este valor foi de $R \$ 58.382 .850,70$ (custo médio de $R \$ 306,49$ por paciente). As afecções relativas aos capítulos XIX e XX corresponderam a $6,27 \%$ desse total com um custo médio de $\mathrm{R} \$ 396,91$ por paciente. O custo médio das hospitalizações por traumatismo foi de $\mathrm{R} \$ 370,66$.

Nas Tabelas de 1 a 6 observam-se os principais tipos de traumatismos com seus respectivos custos, de acordo com a localização do trauma.

Em relação aos custos por diagnóstico, observamos que os Traumatismos na mesoregião Recife, responderam por $77,9 \%$ do total dos gastos, seguido por queimaduras 15,2\% e complicações e seqüelas de causas externas $5,2 \%$. Outras causas externas corresponderam a $1,7 \%$ dos diagnósticos. this total with a mean cost of $R \$ 396.91$ per patient. The mean cost of hospitalizations per trauma was $R \$ 370.66$.

Tables 1 to 6 show the main types of traumas with their respective costs according to the trauma site.

As for the cost per diagnosis, we observed that traumas were responsible for $77.9 \%$ of the total expenditures in the great Recife, followed by burns (15.2\%), and complications and sequelae of external cause injuries (5.2\%). Other external causes corresponded to $1.7 \%$ of diagnoses.

\section{DISCUSSION}

In the present study, the direct costs to the SUS of hospitalizations due to trauma were evaluated; costs of outpatient follow-up following

\begin{tabular}{|c|c|c|c|}
\hline Tipo de trauma / Type of trauma & Número / number & (\%) & Custo / Cost(em reais) \\
\hline Ferimentos / Injuries & 13 & $(0.7)$ & $8.495,01$ \\
\hline Fraturas do crânio, ossos da face e pescoço / Fractures of the skull, face bones, and neck & 238 & $(14.3)$ & $151.031,00$ \\
\hline Traumatismos superficiais da cabeça/Surface head traumas & 60 & $(3.5)$ & $21.854,87$ \\
\hline Traumatismo intracraniano/Head injury & 1.283 & $(76.6)$ & $846.922,45$ \\
\hline Traumatismo do olho e da órbita ocular / Eye and ocular orbit trauma & 82 & $(4.9)$ & $19.694,31$ \\
\hline TOTAL & 1.676 & $(100.0)$ & $1.047 .997,64$ \\
\hline
\end{tabular}

Tabela 1 - Principais tipos de traumatismos em segmento cefálico e pescoço com seus respectivos custos, em crianças e adolescentes, Pernambuco 1999

Table 1 - Main types of trauma to the head and neck with their respective costs in children and adolescents, Pernambuco 1999

\begin{tabular}{|c|c|c|c|}
\hline Tipo de trauma / Type of trauma & Número / number & (\%) & Custo / Cost(em reais) \\
\hline Ferimentos / Injuries & 5 & $(11.3)$ & $1.180,45$ \\
\hline Traumatismos e fraturas / Traumas and fractures & 17 & $(38,6)$ & $1.453,92$ \\
\hline Traumatismos de órgãos internos / Inner organ traumas & 22 & $(60,1)$ & $30.619,25$ \\
\hline TOTAL & 44 & $(100.0)$ & $33.253,62$ \\
\hline
\end{tabular}

Tabela 2 - Tipos de traumatismos torácicos e seus custos em crianças e adolescentes, Pernambuco1999

Table 2 - Types of thoracic traumas and their costs in children and adolescents, Pernambuco, 1999

\begin{tabular}{|c|c|c|c|}
\hline Tipo de trauma / Type of trauma & Número / number & (\%) & Custo / Cost(em reais) \\
\hline Ferimentos / Injuries & 6 & $(2,4)$ & $3.207,61$ \\
\hline Fraturas (pelve) / Fractures (pelvis) & 20 & $(8,0)$ & $18.408,72$ \\
\hline Traumas órgãos internos / Inner organ traumas & 223 & $(89,6)$ & $190.439,23$ \\
\hline TOTAL & 249 & $(100.0)$ & $212.055,56$ \\
\hline
\end{tabular}

Tabela 3 - Tipos de traumatismos abdominais e seus custos em crianças e adolescentes, Pernambuco 1999

Table 3 - Types of abdominal traumas and their costs in children and adolescents, Pernambuco, 1999

\begin{tabular}{|c|c|c|c|}
\hline Tipo de trauma / Type of trauma & Número / number & (\%) & Custo / Cost(em reais) \\
\hline Ferimentos / Injuries & 4 & $(0,1)$ & $1.269,36$ \\
\hline Traumas em partes moles / Soft tissue traumas & 11 & $(0,2)$ & $3.590,37$ \\
\hline Entorses e luxações / Sprain and luxations & 310 & $(7,8)$ & $58.177,09$ \\
\hline Fraturas/Fractures & 3.601 & $(91,9)$ & $815.934,59$ \\
\hline TOTAL & 3.926 & $(100.0)$ & $878.971,41$ \\
\hline
\end{tabular}

Tabela 4 - Tipos de traumatismos em membros superiores e seus respectivos custos em crianças e adolescentes, Pernambuco,1999 Table 4 - Types of arm traumas and their respective costs in children and adolescents, Pernambuco, 1999 


\begin{tabular}{|c|c|c|c|}
\hline Tipo de trauma / Type of trauma & Número / number & (\%) & Custo / Cost(em reais) \\
\hline Ferimentos / Injuries & 7 & $(0,7)$ & $1.071,79$ \\
\hline Trauma em partes moles / Soft tissue trauma & 11 & $(1,1)$ & $5.373,73$ \\
\hline Entorses e Luxaçőes / Sprain and luxations & 75 & $(7,7)$ & $33.295,64$ \\
\hline Fraturas / Fractures & 879 & $(90,5)$ & $494.751,96$ \\
\hline TOTAL & 972 & $(100,0)$ & $535.393,12$ \\
\hline
\end{tabular}

Tabela 5 - Tipos de traumatismos em membros inferiores e seus respectivos custos em crianças e adolescentes, Pernambuco, 1999 Table 5 - Types of leg traumas and their respective costs in children and adolescents, Pernambuco, 1999

\begin{tabular}{|c|c|c|c|}
\hline Tipo de trauma / Type of trauma & Número / number & (\%) & Custo / Cost(em reais) \\
\hline Ferimentos / Injuries & 43 & $(24,1)$ & $7.496,32$ \\
\hline Traumas em partes moles / Soft tissue trauma & 12 & $(6,7)$ & $15.369,61$ \\
\hline Entorses e luxaçöes/Sprain and luxations & 56 & $(31,4)$ & $7.103,87$ \\
\hline Fraturas múltiplas / Multiple fractures & 67 & 37,6 & $26.567,54$ \\
\hline TOTAL & 178 & $(\mathbf{1 0 0 . 0 )}$ & $56.537,34$ \\
\hline
\end{tabular}

Tabela 6 - Tipos de politraumatismos e seus respectivos custos em crianças e adolescentes, Pernambuco, 1999

Table 6 - Types of multiple traumas and their respective costs in children and adolescents, Pernambuco, 1999

Outros custos, não especificados, relacionados com 774 pacientes vítimas de traumatismos, corresponderam a um gasto de $R \$ 91.622,80$. Other not specified costs related to 774 trauma patients corresponded to an expenditure of $R \$ 91,622.80$.

\section{DISCUSSÃO}

No presente trabalho, buscou-se verificar os gastos diretos do SUS com as internações por traumas, sendo deixados de fora os custos com o seguimento ambulatorial após alta e tratamentos de reabilitação. Deve ser levado em consideração que esses custos estão subestimados, uma vez que não foram computados os atendimentos que não resultaram em hospitalizações, ou ainda os que procuraram e não conseguiram atendimento, ou ainda morreram no local da ocorrência, não entrando assim no cômputo geral do SUS.

Em Pernambuco, o custo das internações hospitalares por Causas Externas, no SUS, apresentaram um crescimento de 47,20\% entre os anos de 1996 à 1999. O percentual gasto pelo SUS com todas as internações no ano de 1999 correspondeu a algo em torno de $0,05 \%$ do PIB do estado ${ }^{(3)}$. Estudo pioneiro na estimativa de impacto econômico dos acidentes e violências no Brasil revelou que as internações por estas causas em todo o país geraram um gasto anual que, em 1994, correspondia a $0,07 \%$ do produto interno bruto nacio$\mathrm{nal}^{(6)}$.

Os traumatismos foram as principais causas de internamento no estado de Pernambuco, para todas as faixas etárias, perfazendo $84,7 \%$ e com maiores freqüências na faixa de 5-19 anos. Em áreas urbanas, já se observou que o trauma é uma doença com alto risco de recorrência, pois há um grupo de pessoas que não é apenas vítima de trauma, mas vítima de seu próprio comportamento de alto risco, com taxas de recorrência que podem chegar até $44 \%$ dos casos, quando é possível um seguimento médico adequado risco ${ }^{(8,10,12)}$.

Os traumatismos do segmento cefálico e do pescoço foram os que representaram os maiores custos ao SUS, representando o traumatismo intracraniano $76,6 \%$ dos gastos totais com os traumas da cabeça e do pescoço. Outros estudos apontam esse tipo de trauma, juntamente com aqueles que atingem as extremidades dos membros como os de maiores custos ${ }^{(7,8)}$. Nossos achados indicaram as fraturas dos membros superiores e inferiores, respectivamente como a segunda e a terceira causa de maiores gastos pelo SUS. Mackenzie et al. ${ }^{(7)}$ hospital discharge and rehabilitation treatment were not taken into account. One must remember that costs are underestimated since costs of medical visits with no hospitalization were not taken into account. In addition, patients who were not seen by doctors and those who died where the event took place were excluded from the SUS data.

Costs of hospitalizations due to external causes to the SUS in the Pernambuco state were increased by $47.20 \%$ from 1996 to 1999 . The total costs to the SUS of all hospitalizations in 1999 corresponded to approximately $0.05 \%$ of the GNP of the state ${ }^{(3)}$. A pioneer study of the estimated economical impact of accidents and violence in Brazil has shown that hospitalizations due to these causes throughout the country have resulted in an annual expenditure that corresponded to $0.07 \%$ of the national gross product in $1994^{(6)}$.

Traumas were the main causes of hospitalization in the Pernambuco state for all age groups and totalled $84.7 \%$, with higher frequencies for the group aged 5-19years. In urban areas, traumas are associated with a high risk of recurrence because there is a group of persons who are not only a victim of trauma, but also a victim of their high-risk behavior, with recurrence rates that may amount to $44 \%$ of cases when an adequate medical follow-up is available ${ }^{(8,10,12)}$

Head and neck traumas were those responsible for higher costs to the SUS, head injury being responsible for $76.6 \%$ of the total expenditures of head and neck traumas. Other studies have shown that this type of trauma and those affecting the limb extremities are the most expensive ones ${ }^{(7,8)}$.

Our findings show that arm and leg fractures are, respectively, the second and the third cause of SUS expenditures. Mackenzie et al. (7) observed that limb traumas corresponded up to $43 \%$ of the total costs of treatment

One must emphasize that the overall costs to the public health system due to all types of trauma have notyet been extensively established since indirect costs cannot be evaluated due to the lack of precise data and nonmedical direct costs are difficult to measure. How- 
observaram que os traumas em membros chegavam a representar $43 \%$ dos custos totais com o tratamento.

É importante ressaltar que a mensuração dos gastos para o sistema público de saúde gerado por todas as formas de traumatismos ainda não pode ser realizada em toda a sua magnitude, já que a avaliação dos custos indiretos carece de dados fidedignos que a fundamentem e a própria medição dos custos diretos não médicos é difícil de ser realizada. Entretanto, para que o real impacto dos traumatismos sobre a saúde pública possa ser avaliado, suas repercussões sociais e sobre a força de trabalho produtiva, devidamente mensurada, é fundamental que pesquisas com esse intuito sejam continuamente fomentadas.

Para que políticas públicas de combate ao trauma sejam eficazes, faz-se necessário, em paralelo às medidas de segurança, que a "saúde pública" também estabeleça quais as populações de risco em cada região e quais as características das lesões sofridas por essa mesma população. Isto servirá como subsídio às autoridades, para que possam estabelecer as prioridades peculiares de cada bairro, cidade ou estado.

Os custos diretos médicos, conforme descritos neste trabalho, são elevados e estariam muito melhor empregados se, porventura, pudessem ser aplicados em educação e saúde preventiva e não no tratamento, muitas das vezes paliativo, de lesões que, em níveis crescentes têm sido intencionalmente infligidas. Os custos financeiros para o país têm sido muito elevados, como os têm sido os custos sociais. Urge a busca de soluções em caráter definitivo para este grave problema, que, embora não tenha solução a curto prazo, pode ser combatido em várias frentes e cujos resultados far-se-ão sentir a médio e longo prazos.

\section{CONCLUSÕES}

- Foi elevado o gasto do SUS com a hospitalização de crianças e adolescentes vítimas de traumas no estado de Pernambuco em 1999,

- Traumatismos foram as principais causas de internamentos na população estudada, representando mais de $80 \%$ dentre as causas externas estudadas.

- Os traumatismos que representaram os maiores custos ao SUS foram o traumatismo intracraniano e as fraturas de membros superiores e inferiores.

\section{REFERÊNCIAS BIBLIOGRÁFICAS}

1. Barros MDA, Ximenes R, Lima MLC. Mortalidade por causas externas em crianças e adolescentes: tendências de 1979 a 1995. Rev Saúde Pública 35:142-149, 2001

2. Clancy TV, Misick LN, Covington D, Churchill MP, Maxwell JG. The financial impact of intentional violence on community hospitals. J Trauma 37:1-3, 1994.

3. CONDEPE. Secretaria de Planejamento e Desenvolvimento Social. Pernambuco em Dados. Recife, 2000.

4. Deslandes SF, Silva CMFP, Ugá MAD. O custo do atendimento emergencial às vítimas de violências em dois hospitais do Rio de Janeiro. Cad Saúde Pública 14:287299, 1998.

5. Farrel C. The economics of crime. Business Week 13:72-80, 1993

6. lunes RF. Impacto econômico das causas externas no Brasil: esforço de mensuração. Rev Saúde Pública 31:38-46, 1997 ever, in order that the actual impact of trauma upon public health be evaluated as well as the social repercussions and the impact upon the productive workforce, research studies for that purpose must be continuously stimulated.

In order that public policy against trauma be effective, the public health service must define the risk populations in each region and the characteristics of their injuries and safety measures must be adopted. These data will be used by authorities when defining priorities for each area, city, or state.

Medical direct costs as described in the present paper are high. Resources would be better used in education and preventive programs rather than in the treatment, in many cases only palliative, for increasing deliberately inflicted injuries. Financial costs to the country have been very high, as well as the social costs. The search for definitive solutions is required because the fight against violence-related injuries may lead to medium-and long-term results if short-term results are not to be expected.

\section{CONCLUSION}

The cost to the SUS of trauma-related hospitalizations of children and adolescents was high in the Pernambuco state in 1999.

Traumas were the main causes of hospitalizations in the studied population and corresponded to more than $80 \%$ of those due to the external causes.

Traumas associated with higher costs to the SUS were head injury and limb fractures.
7. Mackenzie EJ, Shapiro S, Siegel JH. The economic impact of traumatic injuries One-year treatment-related expenditures. JAMA 260:3290-3296, 1988

8. McGarry LJ, Thompson D, Millham FH, Cowell L, Synder PJ, Weinstein MC. Trauma 53:1152-1159, 2002

9. Miller TR, Cohen MA, Rossman SB. Victim costs of violence crime and resulting injuries. Health Affairs 12:195-197, 1993.

10. Minayo MCS, Deslandes SF. The complexity of relations between drugs, alcohol and violence. Cad Saúde Pública 14:35-42, 1998

11. Morrison W, Wright JL, Paidas CN. Pediatric trauma systems. Crit Care Med 30(Suppl.):448-556, 2002.

12. Poole GV, Griswold JA, Thaggard VK, Rhodes RS. Trauma is a recurrent disease. Surgery 113:608-611, 1993

13. Weaver K, Maddaleno M. Youth violence in Latin America: Current situation and violence prevention strategies. Rev Panam Salud Publica 5:4-5, 1999. 